Peer-Reviewed Article

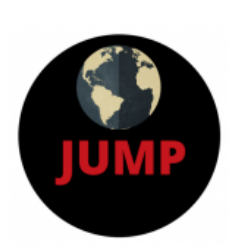

OJED

ISSN: 2574-3465 Print/ ISSN: 2574-3481 Online

Volume 5, Issue SI (2021), pp. 107-116

(C) Journal of Underrepresented and Minority Progress

http://ojed.org/jump

\title{
Socio- Psycho- Religious Responses to Covid-19 in Bangladesh
}

\author{
Suresh R. Basak \\ Metropolitan University, Bangladesh
}

\begin{abstract}
The emergence of the Covid-19 pandemic once again challenged the advancement of modern biological sciences. Man found himself utterly blinded by the nano-Lilliputian corona virus known as Covid-19. Against the background of daily death tolls all over the globe, scientists and researchers spent strenuous days and months to invent Covid-19 vaccines; governments adjusted and readjusted their combat policies, and WHO continued presiding over the conundrum with periodical situation studies and issuing warnings and updates. But a man is, after all, a man-a living symbiosis of social, psychological, moral, and a host of other values beyond the grasp of laboratories and offices. So one might be curious to know, how Bangladesh, in a far-flung corner of the globe, responded to Covid-19 in the early days of the onslaught, then in a one year span, and what the encounter might look like from the perspectives of sociology, psychology, and religion, besides economy. This paper, more theoretical and perceptual than scientific, will examine how the Covid-19 proliferation in Bangladesh affected the sociopsycho-religious equilibrium of her people like the people of the rest of the world. It will further explore how Bangladesh, till this date, managed to bridle the rate of infection and death through strategic policies, and cruised a moderate path to curb down the nascent mass panic and defiant religious dogmatism, followed by a timely vaccination program.
\end{abstract}

Keywords: Covid-19, community transmission, socio-psycho-behavioral patterns, religiosity, strategic policies, herd immunity, vaccination. 


\section{INTRODUCTION}

The sudden onset of Covid-19 pandemic caught the world completely unprepared. The monumental advancement of medical sciences stood utterly perplexed and clueless. It was an unbelievable spectacle ever witnessed by mankind. It was equally unthinkable how fast it travelled continents in a matter of weeks. The powerful governments (in all nuances of meaning) found themselves in a state of total disarray. The corona virus turned everything upside down. Nature's modus operandi of retaliation over man's daily encroachment upon nature proved once again inevitable, subtle and incalculably destructive. Not to speak of the threatening giant viruses lying under permafrost (Giant virus, 2015), just a species of Chinese virus proved enough to unsettle the whole world.

\section{The Global Scenario and Bangladesh Situation}

Historically, mankind had been through wars, famines and epidemics every now and then with much higher tolls, but never got so lost, panicky and unarmed as with the onslaught of Covid-19. The social media got flooded with videos of wild animals moving out to the streets, and men bolting the doors of their homes! Towns, cities and countries, one after another, closed their borders, suspended flight operations. Lockdowns came into force; all economic activities were abruptly halted. The familiar scenes of crowded streets, traffic jam, noisy malls, busy offices and educational institutions turned unfamiliar. The lead news in the media was corona virus and the number of infected, recovered and dead patients all over the globe, its acceleration, preventive measures, WHO's routine bulletins etc.

The global tour of the Chinese virus (November 17, 2019) spared no unwilling host, rich or poor, spared no worlds - the First, Second or the Third. The equilibrium of the societies, politics, economics, cultures, life-styles, religious faiths, and psycho-behavioral patterns of people experienced a terrible jolt all over the globe that redefined and restructured the strategy of survival of every country. Parallel to the scientists' ongoing struggle for inventing and marketing Covid-19 vaccines to disempower the corona virus and its killing capacity to a zero level, a chaotic spectacle of national, societal and individual psycho-physical responses to Covid-19 started surfacing as the constant flow of information continued pouring in. Based on ever-changing data of the Covid-19 onslaught, a conceptual study on a particular country can be of interest to show how the concerned people offered diverse responses to a fatal disease like Covid-19. The focus of the present article is centered on Bangladesh and her people's socio-psycho-religious responses to Covid-19. But for the long stay of the virus, nature of the fluidity of data, inadequate 
tests, and reliability of the sources related to the figures of the infected, cured and dead, the article restricts itself to a premise more theoretical than scientific and more inferential than conclusive. Moreover, in the passage of one year, the change of physical, psychological and societal approach to Covid-19 in Bangladesh (as in other countries) along with the virus's indefinite stay restricts the article further to articulate any plausible conclusion.

\section{Bangladesh: First Detection of Covid-19}

The first three patients infected with Covid-19 were confirmed on 8 March, 2020 in Bangladesh by the country's lone epidemiology institute, IEDCR. According to WHO- situation report (05 March to 05 October 2020), the total number of the corona-virus cases is 2,001,431; confirmed cases 370,132; recovered cases 283,182 and dead 5,375 (Corona virus disease, 2020). But worldometers.info reports on 7 October 2020: the number of corona-virus cases is 371 ; deaths 5,405 and recovered 284,833 (Worldmetre) year later, on 01 March 2021, WHO- situation report -53 (Morbidity and mortality, 2021) gives staggering figures: confirmed cases stood to 546,216; recovered cases 496,924, and death 8,408. The country's ability for conducting Covid -19 tests went up proportionally to a higher figure of $4,044,027$.

The news of Covid-19 eruption in China, even when reported extensively in the news and electronic media in Bangladesh, spread little concern in the public mind. Most people took it casually as if it were a distant problem of a distant country. On 01 February 2020 Bangladesh Biman, the national carrier, evacuated as many as 312 stranded Bangladeshis from Wuhan. Though it left little ripples of concern over the majority of people, it triggered suspicious angst among the conscious and educated elite of the country. To a great relief of all, they all tested negative. It was stated earlier, the first three corona-virus cases were detected on 08 March 2020 and two of them were returnees from Italy. In the meantime Italy got itself entrapped into the worst pandemic scenario: it turned into the epicenter of Covid-19 in Europe. On 15 March 142 Bangladeshis returned from Italy to Dhaka. The fiasco of health check and impatient wage earners, though grimly taken, signaled a high risk of spreading the virus to the far-flung areas the returnees would travel. This sent a nervous cold wave across the nation. That was the onset of the onslaught. Against this background of nationwide concern, the government decided to scale down the Father of the Nation's birth centenary on 17 March 2020 (Bangabandhu's birthday, 2020). It was followed by closing down of all educational institutions; sporadic and all-out lockdown; 
closure of mills, factories and supermalls; gradual restrictions on roads and highway traffic and air flights. Bangladesh structured and restructured its strategy to combat against this formidable virus relying more on the ministry of health and the lone epidemiology institute excluding the private health service sector (Cousins 2020) reported "The Lancet", 29 August 2020. It might be worthwhile to observe how a society, composed of diverse faiths, classes, ethnicities and their financial strengths/ weaknesses - elite-non-elite, literate-illiterate, Bourgeoise-Proletariat all put together-responded to this long- term havoc.

\section{Early Days of Covid-19 and Its Impact on Various Sectors}

Initially there was a dead lack of concern about the new virus even when it had already infiltrated into the country. A nation that had the experience of battling malaria, cholera, dengue in epidemic scale, besides other regular killer diseases, took it more or less casually. With lockdowns on, an entrapped population cautiously monitored this endgame. Like bystanders, they gaped at the empty alleys, roads, streets and highways and heard only the sirens of ambulances and peals of the police patrol cars. Few dared steps outside. This was clearly a sign of shock and vulnerability.

The lower strata of the society living under the poverty line that sharply rose from $20.5 \%$ in June 2019 to $29.5 \%$ in June 2020 faced the grimmest reality. The slum people, pavement-dwellers, vendors, rickshawpullers, hired day laborers etc. were on the top of the worst sufferers. Along with the previously recorded poor, a new set of lower middle class poor emerged; 'tens of millions of people' lost 'their jobs' which "brought them below the poverty line" (Bhuiyan, 2020) What the report missed was that in many private sectors, salary got dwindled into a half or even less. Though government and voluntary organizations came up with aids to help temporarily the non-earning families, but no aids could be given for eternity. The lower middle-class people could hardly bring them down to line up for relief materials and photo sessions; they were sandwiched between dignity and empty wallet. The result was an existential crisis -either defy lockdown and earn or perish. The mantra of wearing masks and maintaining social distance started losing grip over their innate habit; the call of hunger turned out to be more powerful than the fear of disease and death. Only a conscious segment of the population, like the Pope among the sinners, followed the government and WHO's guidelines. The ignominious burial scenes of Covid19 induced deaths - burial personnel with protective gears on, no relatives nearby, wrapped dead bodies pulled and dropped into graves - poked up an unimaginable horror. The social media played a dark role in multiplying the 
intensity of mass phobia. The grossness of the final ritual, however, subsided with the introduction of a better coordinated humane plan. The procession of death, in addition to its crudity, could not deter people in the least to begin a new way of life, accepting the reality and adjusting to it. Call it normalcy or not, it was the social behavioral pattern that brought the airs of normalcy in an otherwise pandemic situation.

\section{Lockdown Withdrawn: Socio-economic Concerns}

To run the wheels of economy, rather to salvage it, the government partially eased lockdown on 30 May 2020 and allowed some garment factories, small business holdings to operate following the government's health guidelines (Sakib 2020). Partial withdrawal, however, soon paved the way for a final good bye to lockdown. Once the sluice gate of lockdown was lifted, people took it for a safe return to old life and life-style, as if, coronavirus were a nonexistent threat. That tells why the graph of the suspected, infected and dead people rose high and higher till mid-October 2020. The necessity of keeping alive, on the one hand, and inadequate healthcare strategies, on the other hand, reflect a social mind-set which is diehard for survival but dismissive of the consequences, restorative in values but carefree in behavior. This explains why even in mid-October the official daily death toll fluctuated from 25 to 30 . Sociologically this is a third world scenario: densely living illiterate, half-literate or literate people, economically struggling, habitually opinionated and all-knowing, fighting against an unknown virus with their old attitude and blind apathy. It is to be remembered, Bangladesh has a population of 165,830,170 as of Monday, March 8, 2021 with a density as high as 1265 per sq.km (Countries in the world, 2020).

\section{Psychological Responses to Covid-19}

The above sociological factors overlap with many of their psychological counterparts. Their major problem lies in not understanding the invisible destructiveness of the virus which made the people, in return, more defiant and aggressive and less rational and cautious. In plain terms, psychology is the science of mind that analyzes how under a given situation human mind receives and reacts to the situation. The process of shaping the reception and reaction entails the whole gamut of individual mindset, insight into things, individual, familial and institutional grooming, and social behavioral pattern etc. This has been quite evident in the mass psychological responses to Covid-19 in Bangladesh. In a highly stratified society where divides exist in the form of educated and un/half-educated, hygiene conscious and hygiene blunt, pro-past and pro-present, individualistic and herd-minded binaries, not to speak of the cliché wealthy- penniless, town-rural dialectics. 
The rampage of Covid-19 exposed this eternal dichotomy more than ever. Many stepped out of the door to struggle for livelihood and many to safeguard their jobs while many more went out for not-so-urgent shopping, strolling and road-side chitchat. Particularly the young people, either out of their youthful adventurism or under the false notion of their non-vulnerability to Covid-19 related infection, emerged as a defiant social group. We saw in the early days of Covid-19 infiltration the students crowding in the tourist spots, especially sea-beaches, and where not. But Bangladesh government closed down all educational institutions to force them stay at home and attend online classes. The Don Quixotes mistook the national crisis for a virus-born summer vacation. The media of all nomenclatures ran picaresque videos of unmasked thousands and (un)social distancing in the streets, markets and other likely places. The government's repeated appeal and instructions fell on their deaf ears. Only the solvent elderly people with records of previous complications seemed to smell the danger and stayed cautious. The higher death rate of this age group might have made them extra watchful, or the death toll could have gone higher. Another psychological (sociological too) trajectory of the prolonged pandemic is the suppression of the real causes of deaths of many people by their relatives. It could not be ascertained whether the deaths were due to Covid-19 or other diseases. Natural deaths are very likely, but the fresh memory of the Covid-related burials, restrictions on the proximity of the relatives of the dead for health reasons (there had been cases of selfwithdrawal) and other elaborate rituals (not excluded but abridged) could have left an impact on concealing facts. If we hypothetically take these cases (in absence of valid records) as manipulated ones, then the mass psychosociological syndrome cannot be ruled out. Again the reported events of socially boycotting neighbors, leaving the infected and the deceased in the hospitals by their family members, throwing away suspected elderly parents by their children, even denying the deceased to have burial in local graveyards etc. in the early days of the pandemic speak more of psychological phobia than pragmatic caution (Bangladesh to ban all rallies, 2020). Covid-19 related fear and deaths are now an accepted reality. This pandemic struck first human physiology, then human psychology wrecking every norm of life and values of society, and thus adding an enormous load of anxiety, depression, morbidity, phobia and helplessness leading to the extent of committing suicides (Bangladesh to ban all rallies, 2020).

\section{Religious Responses to Covid-19}

Like the rest of the globe Covid-19 left a deep impact on the belief systems, religious rituals and practices in Bangladesh. It's a country of diverse 
faiths with Muslims forming the majority (about 90\%), and Hindus, Buddhists, and Christians comprising the rest (10\%). Bangladesh is widely known as a moderate Muslim country where, besides the constitutional guarantee of freedom of religion, people are accommodating and tolerant to other faiths. By and large they are God-fearing, religious, ritualistic, and persevering to uphold the tenets of their faith, even though at times it borders on dogmatism. The pandemic unexpectedly halted the spontaneity of religious duties like daily and weekly Friday prayers in the mosques, pujas in the temples and pagodas, Sunday prayers in the churches. It robbed the colors of the festivities during the last two major Muslim festivals - Eid-ul-Fitr and Eid-ul-Adha. In the meantime, major Muslim countries in Asia like Saudi Arabia, Indonesia and Malaysia imposed restrictions on mass prayers to control the community transmission. Saudi Arabia banned prayers at mosques over corona-virus fears, Aljazeera reported 20 March 2020 (Saudi Arabia bans prayers, 2020). A three-day religious mass gathering in Indonesia was cancelled in March 2020 (Subdued Eid al-Fitr in India, 2020). The Malaysian gathering in March 2020 proved to be fatal as the cases of corona-positive pilgrims had already carried the virus to their home countries, and 550 infections were reported (Subdued Eid al-Fitr in India, 2020). BBC reported on 19 March 2020, close to 30,000 people gathered at Raipur in Bangladesh for a mass prayer; this was convened, without the local government's permission, to offer a special prayer for protection from Covid-19. Then dictated by precaution and prudence, the government of Bangladesh "banned all political, social, and religious rallies and gatherings in the country" (Doza 2020) The religious responses to Covid-19 in Bangladesh eventually turned out to be dichotomous in nature: some followed the health-guidelines without being less religious, and some defied the scientific warnings out of a combative religiosity. Videos on the social media went viral claiming that the corona-virus could do no harm to the faithfuls. The undecided mass thus tossed between the fear of real death and assurances of the voluble preachers while the procession of death went on unabated. The state of the religious conundrum, like genome mutation, slowly but steadily got tuned to some religiously pragmatic adjustments.

\section{Major Religious Festivals: Apprehension and Reality}

The two major religious festivals of the Muslims Eid ul Fitr and Eid ul Adha, and the Durga Puja of the Hindu Community were observed during the last pandemic year. In anticipation of a traditional country-wide shopping spree, particularly during Eid ul Fitr, the government reiterated the usual warnings. In response to the government's call, the elite shopping centers 
assured the government of adequate sanitization and proper distancing. But in reality, crowds of undaunted men and women and children were found elbowing one another in the shopping malls. Though 'No Mask, No Entry' was effective in most of the posh malls, the small shopping places, bazaars, and cheap markets bothered little about health and hygiene restrictions. The psychology of attaining natural hard immunity, and the ideology of 'noncontamination' on the part of the faithful made the crowd even bolder. It got clearly manifested in the frenzied pre-Eid days. Caught between two matrices-religious sentiments and good governance-Bangladesh government chose a cautious middle course to contain the situation. The government restricted mass prayers in Eidgahs and open fields, and gave directives to put on mask and maintain social distance during Eid congregations. The measures, to a large extent, proved to be useful to curb the pandemic. (Subdued Eid al-Fitr in India, 2020). Despite administrative efforts, the post-Eid ul Adha Bangladesh saw a rise in Corona-related death after a low trend. On August 4, 2020 the Ministry of Health confirmed the rise: 50 more died in last 24 hours, raising the figure to (Kamruzzaman, 2020). A low profile Durga puja of the Hindus, besides a more student-oriented Saraswati puja (Saraswati being the deity of learning), drew a sizeable number of devotees. With masks on or off, social distancing in such gatherings could hardly been ensured. This pandemic put all the religious communities to test to figure out the difference between the spirit of religion and paraphernalia of rituals.

\section{Covid Vaccination: Hesitation and Enthusiasm}

Bangladesh launched countrywide Covid vaccination program on 7 February2021. It was a bold and farsighted step taken by the government. The Economist reported on 27 January 2021, "More than 85 poor countries will not have widespread access to coronavirus vaccines before 2023" (More than 85 poor countries, 2020). In the first month of the inoculation campaign, $3,682,152$ doses (first dose) were given (Our World in Data) in Bangladesh. The administration of doses was primarily based on age and vulnerability of profession. The government assured lower age groups would be gradually vaccinated. What might be a daunting task is to vaccinate hundreds and thousands of teachers at different levels-- from primary to university-both public and private, besides the frontline doctors, nurses, technicians etc. The laudable role of the head of the government was to stick to the commitment; the vaccination of the teachers started in March 2021 while that of the frontline health workers started a month ago, on 7 February 2021. It is to be remembered that all educational institutions of the country remained closed, 
under government circular, from 17 March 2020, and the government announced to reopen the schools and colleges from 30 March and the universities from 24 May 2021 (Bangladesh announces reopening universities, 2021). In order to ensure the safety of the students, the teachers' vaccination was given a priority.

While some of the first world countries hesitated to start vaccination, Bangladesh government displayed an unhesitant and sagacious stance to ensure vaccine procurement and begin a massive inoculation program. The dialectic of hesitation and readiness on the part of the people was also explicit in the first one or two days. A lot of misgivings and misinformation went into the making of this religious, socio-psycho dilemma. It was, however, dispelled shortly; registered people spectacularly thronged the vaccination centers in an air of festivity. This can be interpreted as a major shift in public attitude.

\section{CONCLUSION}

Time is not yet ripe to reach a conclusion as we are yet to see the end of the pandemic. With spectacular mask-less crowds streaming on the roads, malls, prayer houses, virtually everywhere, maintaining little or no social distancing, and then against the backdrop of a huge number of unvaccinated people, it is yet to see where we stand. And as it appears, we will have to go more miles before we win over Covid-19.

\section{REFERENCES}

Bangladesh announces reopening universities in May amid vaccination rollout. (2021). Xinhuanet, http://www.xinhuanet.com/english/202102/22/c 139759273.htm

Bangladesh to ban all rallies and gatherings after corona-virus advice defied. (2020, March 03). Badnews24. Retrieved 12 October 2020, from https://bdnews24.com/Bangladesh/2020/03/20

Bangabandhu's birthday centenary programmes postponed. (2020, March 09). The Daily Star. Retrieved 20 October 2020, from http://www.thedailystar.net

Bhuiyan, A.K.M. Ishrafil et al.(2020, October 3). COVID-!9-Related Suicides in Bangladesh due to lockdown and economic factors: Case study evidence from media reports. Retrieved 20 October 2020, from http://www.researchgate.net>publication

Corona-virus disease (COVID-19) Bangladesh situation reports. Retrieved 7 October 2020, from https://www.who.int.>emergencies

Corona-virus: Bangladesh mass prayer event prompts alarm. (2020, March 19). Retrieved 21 October 2020, from http://www.bbc.com.news.world Countries in the world by population. (2021). Worldmetere, https://www.worldometers.info/world-population/population-by-country/ 
Cousins, Sophie. (2020, August 29). Bangladesh's COVID-19 testing criticised.

World Report, 396, 591, https://www.thelancet.com

Covid-19 impact: National poverty rate rises to $29.5 \%$ as of June. (2020, October 12). Dhaka Tribune, Retrieved 12 October 2020, from http://www.dhahatribune.com

Doza, M. Bodrud et al. (2020, June 26). Psychosocial and socio-Economic crisis in Bangladesh due to COVID-19 pandemic: A perception-based assessment. Retrieved 20 October 2020, from http://www.frontiers.org

Giant virus from permafrost. (2015). Nature 525, 16, https://doi.org/10.1038/525161e

Kamruzzaman, Md. (2020). COVID-19: Bangladesh sees rise in deaths after 4 days. Anadolu Agency, https://www.aa.com.tr/en/asia-pacific/covid-19bangladesh-sees-rise-in-deaths-after-4-days/1931096\#

More than 85 poor countries will not have widespread access to coronavirus vaccines before 2023. (2020). The Economist, https://www.eiu.com/n/85-poorcountries-will-not-have-access-to-coronavirusvaccines/\#: : :text=For $\% 20$ most $\% 20$ middleincome $\% 20$ countries, before $\% 202023 \% 2 \mathrm{C} \% 20$ if $\% 20$ at $\% 20$ all

Morbidity and mortality weekly update (MMWU). (2021). WHO Bangladesh COVID-19, 53, https://www.who.int/bangladesh/emergencies/coronavirusdisease-(covid-19)-update/

Sakib, SM Najmus. (2020). Bangladesh may see coronavirus peak next week. Anadolu Agency, https://www.aa.com.tr/en/asia-pacific/bangladesh-maysee-coronavirus-peak-next-week-experts/1845133

Saudi Arabia bans prayers at mosques over corona-virus fears. (2020, March 20). Retrieved 21 October 2020, from http://www.aljazeera.com>news.

Subdued Eid al-Fitr in India, Bangladesh amid coronavirus crisis. (2020). Aljazeera, https://www.aljazeera.com/news/2020/5/25/subdued-eid-al-fitr-in-indiabangladesh-amid-coronavirus-crisis

Worldmeter. (2021, March 13). Retrieved 7 October 2020, from www.worldometers.info $>$ bangladesh

SURESH R. BASAK, Ph.D., is Professor of English, Treasurer, and Dean, School of Humanities and Social Sciences, Metropolitan University, Sylhet, Bangladesh. Widely known as an author, researcher and translator, Professor Basak has so far published more than one hundred and fifty articles, essays and reviews, editorials in various journals (English and Bengali), and twenty-one books from renowned national (including Bangla Academy) and international publishers. He was awarded with the prestigious Bangla Academy Literary Award 2020 for his contribution to literature in translation. Email: sbasak@metrouni.edu.bd.

Manuscript submitted: November 5, 2020

Manuscript revised: February 4, 2021

Accepted for publication: March 5, 2021 